\title{
Piracy off the coast of Somalia: implications for China's maritime security
}

Manickam Venkataraman ${ }^{*}$

*Correspondence:

drvenkat65@gmail.com

Department of Defence

and Strategic Studies, School

of Politics and International

Studies, University of Madras,

Tholkappiar campus,

Chepauk, Chennai, Tamil

Nadu, India

\begin{abstract}
Piracy off the coast of Somalia in the Gulf of Aden in the Indian Ocean region has become a significant non-traditional security challenge to many nations. The increasing number of such attacks as a result of failure of Somali government to tackle its internal problem drew the attention of international community who lent a drastic response thereby curtailing the number of such incidents significantly now. The intensity of the attacks had its implications on international shipping and maritime security of near and distant countries like China, which has of late become assertive. This article aims to analyze the inter-connection between failed states and piracy and the consequent maritime security implications for China. The article adopts qualitative approach using descriptive and analytical methods depending primarily on secondary sources such as published literatures and archival and internet sources. The article concludes that the implications of Somalia piracy to China's maritime security was so grave that China was compelled to join the international community by taking part in the multinational naval task force to combating piracy signifying a cooperative role and at the same time utilizing the opportunity to come closer to Somalia by way of reopening its embassy and engaging in bilateral economic ties. This article is divided into seven broad sections. Besides the introduction, the second section provides the conceptual note on piracy and maritime security. The third section highlights the methodology while the fourth section discusses the background on Somalia and its failed status while the fifth section brings out a short glimpse of Somalia piracy and its method of operation. The sixth section analyzes the role of China and its maritime security implications and the last section provides the concluding remarks.
\end{abstract}

Keywords: Piracy, Maritime security, Non-traditional security threats

\section{Background}

Piracy off the coast of Somalia, although has reduced significantly of late, has nonetheless drawn the attention of international community to a great extent. The piracy itself was a product of Somalia's lack of capacity to govern itself and secure its coastal regions. The failure of the then incumbent Somali Government of General Siad Barre to control the growing discontentment among the thousands of Somalis led to internal unrest and consequently produced civil war that is yet to see any concrete solution. Interesting to note in this development was the poaching by international shipping vessels off Somali coast that prompted to resorting to piracy by those Somalians whose livelihood

(c) 2016 The Author(s). This article is distributed under the terms of the Creative Commons Attribution 4.0 International License (http://creativecommons.org/licenses/by/4.0/), which permits unrestricted use, distribution, and reproduction in any medium, provided you give appropriate credit to the original author(s) and the source, provide a link to the Creative Commons license, and indicate if changes were made. 
depended on fishing and who were deprived of it owing to the incapacity of the state to secure them the livelihood that they very much banked on.

An upshot from the above is the rise of piracy off the Somalia coast, which drastically affected all international commercial shipping that passed through the Gulf of Aden. It threatened international sea lanes of communication including that of China whose international trade with the outside world increased commensurate with its increasing economic activities. Reactions from the international community culminated in the form of constituting a multinational naval task force in 2008 to combating piracy. Interestingly, China for the very first time sent its ships to take part along with the international task force. Not only that, China also decided to re-open its closed embassy in Mogadishu after 23 years of break-up in diplomatic relations besides helping to enhance Somalia's capacity to secure its borders ${ }^{1}$ including that of its long coast line that has largely been under the control of pirates. How and to what extent China's maritime security affected by the Somali piracy? What prompted China to play such role along with the international community? This article seeks to analyze the link between failed states and piracy and its implications for China's maritime security.

\section{The concept of piracy and maritime security}

Piracy can be understood in different ways by different people as one that is conducted in international waters. However, a legal understanding is necessary that delineates clearly the very concept of it. According to the 1982 United Nations Convention on the law of the sea (UNCLOS) article 101, is defined as follows:

a. Any illegal acts of violence or detention, or any act of depredation committed for private ends by the crew or the passengers of a private aircraft, and directed,

(i). On the high seas, against another ship or aircraft, or against persons or property on board such ship or aircraft;

(ii). Against a ship, aircraft, persons or property in a place outside the jurisdiction of any state;

b. Any act of voluntary participation in the operation of a ship or of an aircraft with knowledge of facts making it a pirate ship or aircraft,

c. Any act inciting or of intentionally facilitating an act described in sub-paragraph (a) or (b)".

There is however a distinction between piracy and "Armed robbery against ships". Armed robbery against ship is defined in the code of Practice for the investigation of crimes of piracy and Armed robbery against ship (UN resolution A. 922 (22) paragraph 2.2) as follows:

Armed robbery against ships means any unlawful act of violence or detention or any act of depredation or threat thereof, other than an act of "Piracy", directed against a 
ship or against person or property on board such ship, within a states jurisdiction over such offences ${ }^{2}$

Another useful definition on piracy is by Martin N. Murphy who in his book "small boats, weak states and dirty money" (2009), defines "piracy, very simply, is unlawful depredation at sea involving the use or threat of violence possibly, but not necessarily, involving robbery... Piracy, while not a political crime, has invariably been linked to politics and the expression of state power, or more commonly weakness..." In the same vein, the International Maritime Bureau annual report 2009 defines piracy and armed robbery as:

An act of boarding or attempting to board any ship with the apparent intent to commit theft or any other crime and with the apparent intent or capability to use force in the furtherance of that act ${ }^{3}$

Although the definition of what constitutes piracy is clear, what is not clear is with regard to piracy committed within the territorial waters by countries that are considered failed states such as Somalia. Even the 1982 UN Convention on Law of Seas (UNCLOS) doesn't spell out adequately such matters and hence the legality of the issue remains problematic. ${ }^{4}$

As for as security is concerned, in the traditional sense it is understood as security of the state from external military attack or as protecting the national interests or as a global security from nuclear catastrophe (UNDP 1994). However, since the events leading to 11 September 2001 a paradigm shift on the notion of security ${ }^{5}$ has taken place in the form of increase in a wide-array of threats such as terrorism, drug trafficking, civil wars and not least maritime security-all of which are now viewed as non-traditional security threats. There is, according to Barry Buzan (quoted in Rahman 2009, p. 9) an economic dimension to security that can be applied at all levels of analysis. And in this economic dimension there is also a maritime element, which according to Barry (2009, p. 203) is equally important since the secure operation of global markets can be threatened by external forces such as piracy and war. So what then is maritime security?

For obvious reasons, the term maritime security denotes threats that arise at the maritime domain. Bueger (2015, p. 2) in his evocative discussion on the subject categorizes the various arguments on maritime security as negative and positive-negative because threats such as inter-state disputes, maritime terrorism, piracy, drug trafficking, arms selling, illegal fishing etc., should be absent and positive because it means maintenance of "good" or "stable" order at sea. The other positive dimension that Christian Bueger mentions is the linkages between maritime security and economic growth. Of course, in conceptualizing this, questions such as whose economic growth and whose stable order do these definitions imply arise pointing to the lack of unanimity and prevalence of confusion in understanding maritime security among scholars alike. Be that as it may, this research utilizes the economic growth approach since it includes "calls for more coordination, information sharing, regulation, law enforcement and capacity building". As will

\footnotetext{
${ }^{2}$ See ICC (2010).

${ }^{3}$ See ICC (2010).

${ }^{4}$ See Somali Piracy Exposes Weakness in UN Law of the Sea (2015).

${ }^{5}$ See for an excellent discussion on the concept of security, Buzan (2009), see also Rahman (2009).
} 
be discussed below, China has not only taken steps to coordinate and share information among international community on the issue but has also sought to engage Somalia by way of capacity building.

\section{Methods}

The issue of Somalian piracy questions how and to what extent the piracy had implications for maritime security of distant countries like China and consequently how China reacted to it. Hence, to the effect that this article focuses on the interface between piracy and its implications on China's maritime security it employs qualitative methodology using descriptive and analytical approaches since a better understanding on the issues raised here could be done only by tracing the developments over time qualitatively. Noting that qualitative study allows for investigation of a phenomenon through a variety of sources the tools for gathering data-primarily secondary in this case were diversified in order to generate sufficient data to help analyze the problem. Accordingly, data for the article were predominantly collected from relevant published literatures and other secondary sources including newspapers as well as the huge data base that exists in the form of e-resources. Besides, ideas and inputs from informal discussions with fellow colleagues during my service at Addis Ababa University, Ethiopia helped frame the context of the article. The data collected were described and analyzed chronologically to help arrive at a conclusion.

\section{Background: Somalia and its failed status}

It is important at the outset to have a short glimpse at the failed status of Somalia and its repercussions. Located strategically on the red sea coast close to the Middle East and on the path way of most important shipping lanes in the east coast of Africa, North of the Equator between the Gulf of Aden on the North and Indian Ocean in the east, Somalia borders Djibouti on the Northwest, Ethiopia on the West, and Kenya on Southwest. It occupies a key position in the Horn of Africa between the Arab Peninsula and the African continent. The Republic of Somaliland broke away from the mainland in 1991 but has not been able to gain international recognition except by few neighbouring states like Ethiopia. The semi-autonomous region Puntland became a self-governing entity in 1998 but still considers itself part of Somalia and the remaining regions in the South and the centre is currently engulfed in factional and sectarian violence since 1991. Somalia's population in 2012 was estimated at 10,195,000 and the country has an area of 637,657, square kilometres, its GDP in the same year was put at USD $1306.00 .{ }^{6}$ The Somalis had developed intense contact with the Persian and Arab immigrants at early stages which shaped their lifestyle, language and culture immensely (Elmi 2010).

Since attaining independence in July 1960, Somalia has been under political turmoil. The democratic political system that was put in place after independence was short lived. Primarily due to financial and administrative incapacity, successive civilian governments was not able to pull along and in October 1969 Somalia witnessed a bloodless coup which brought Major General Siad Barre to power turning the country into a socialist state in which all able bodied citizens were compelled to undergo military training. He

\footnotetext{
${ }^{6}$ See UN Data Somalia (2015).
} 
ruled the country as a despot until his overthrow in 1991. Obviously, Barre's totalitarian rule provided the necessary incentive for his own downfall. His centralized administration manifested by militarizing the state without any opposition; the abrogation of the national constitution; dissolution of the elected National Assembly and appointment of people to important positions of power based on their affiliation and loyalty than merit; and bringing Somalia under a socialist ideology in tune with the then Soviet Union-all of them and many more put a full stop to his rule (Lewis 2003).

With the mismanagement of Somalia's political terrain by Siad Barre's regime, warlords emerged along clan lines carving out enclaves and becoming very influential by smuggling just anything. In spite of Somalis being a homogenous people, unlike most other African societies, with common religion, "clanism" has what has questioned the homogeneity. Somalis are organized along clan lineages and hence traditionally, conflicts are solved by local clan elders. Hence all attempt by the international community to put an end to the crisis in Somalia failed. Notable among them were the initiative by the subregional organization Inter-governmental Authority on Development (IGAD) and other individual member countries of the Horn of Africa such as the Arta conference organized by Djibouti in 2000 that brought in the existence of Transitional National Assembly under Abdul Qasim as Interim President for 2 years and later the Eldoret peace initiative at Kenya in August 2003 that created another transitional government but this time with a new and significant addition of Federalism and which was called as "Transitional Federal Government" under the Presidentship of Abdullahi Yousuf Ahmed. Although the federal concept would provide the necessary glue to all war lords to chip-in, yet, it failed as it was perceived to be orchestrated by neighbouring Ethiopia, which happens to be its arch-enemy. Besides, each warlord desired to retain their power and if at all they lose, they do so only with their death and at that point of time, their descendants belonging to their own clan would take over power. Any sharing or disbursement of power to other clans or tribes would not be welcomed by the war lord.

By 2006, in view of lack of any agreement from among the different clans on the manner in which Somalia should be governed extremist Islamists such as Al-Shabaab with claims to Somalia's political power and very egregiously inflamed the conflict. In the process Somalia turned into war zone leading to increased poverty, unemployment and migration to neighboring countries like Ethiopia and more importantly turning to piracy.

Addressing this issue, Fukuyama (2004) argues that "weak or failed states are close to the root of many of the world's most serious problems" and these range from poverty and various diseases to drug trafficking and terrorism, whose occurrence in one part of the world have a direct or indirect consequences on the rest of the world. It is obvious therefore that the strength or weakness of a state is a matter of international significance

\footnotetext{
7 President Abdullahi has been portrayed as a supporter of Ethiopia and it dates back to the 1977 Ogaden war in which Somalia fought Ethiopia over the issue of sovereignty over Ogaden region and lost the war. Ogaden region is now under the control of Ethiopia and is supposed to be a fertile region in the whole of Ethiopia and claimed by the Union of Islamic Courts (UIC) of Somalia even now. President Siad Barre blamed his military generals for his defeat at the hands of Ethiopia and even went to the extent of putting several of his generals to death. Colonel Abdullahi was one of those prominent military officers who escaped to neighboring Kenya and later took refuge in Addis Ababa, Ethiopia where he started an opposition party for the first time against Siad Barre rule. The fact that Siad Barre had an opposition based in Ethiopia was enough for the Somalis to believe that it has been aided and abetted by Ethiopia. And the fact is that, the present Ethiopian government of EPRDF has extended its support to Abdullahi and was even instrumental in the installation of Abdullahi as leader of the Transitional Federal Government.
} 
and no more it can be taken lightly. However, it matters a lot whether a state has the capacity to command loyalty, maintain essential elements of sovereignty, a monopoly over the legitimate use of force and the ability to garner enough resources that are necessary to rule (Holsti 1996). Hence, various interconnected components go to determine the strength or weakness of a state and they are the idea of the state itself, the physical basis, and the government machinery. Where these elements are well connected, their prospect to sustain and support each other will be strong. And if not, then we may term it as "failed states" - political entities that have collapsed or are on the verge of collapse. This is a state of affairs where there is no public order, ineffective command of authority and loyalty and groups of all sorts and factions attempt to resist those who might try to integrate the community to establish effective order.

\section{Rationale for Somali piracy and its method of operation}

The piracy in Somalia revolves around the Somali territorial waters, the Gulf of Aden and the Indian Ocean (Fig. 1). It has the longest coastline of about $3025 \mathrm{~km}$ in continental Africa. However the Puntland region of Somalia constitutes the critical axis of the Somali piracy as over $90 \%$ of the Somalians involved in piracy are from Puntland. Land bases of the pirates are also found in the Puntland communities from where they launch out to sea. Besides Puntland, the other region from where piracy network was operating was the Mudug region in the Southern part of Somalia. ${ }^{8}$

Tracing the origins, Murphy (2009) indicates that much of Somali piracy appears to have its roots in fishing disputes. ${ }^{9}$ The absence of any effective authority operating along Africa's long national coastline has meant that fishing vessels from Europe and East Asia could exploit the area's rich marine resources at the expense of locals causing dangerous tensions. In other words, the Somali fishermen became increasingly challenged by well organized and sophisticated international fishing vessels from Europe and elsewhere (Fig.2). The Somali fishermen could not simply stand this competition from international fishing firms and hence they simply turned to piracy. This argument falls within the mainstream of most stories tracing the origins of Somali piracy but though not exhaustive as many other strands have since emerged. Some commentators argue that the main sources of piracy in the region is armed groups, formed by local fishermen in response to illegal, unreported and unregulated fishing (IUU) by foreign fishing vessels, which subsequently become pirate gangs. ${ }^{10}$ For example, a July 2005 report from the United Kingdom Department for International Development (DFID) estimated that Somalis lost $\$ 100$ million to illegal tuna and shrimp fishing in the country's exclusive economic zone in 2003-2004. ${ }^{11}$ What is noteworthy in this argument is the economic dimension to security, which the ordinary Somali men faced that later translated into maritime element in the form of pirate attacks in order to protect their own livelihood. ${ }^{12}$

\footnotetext{
${ }^{8}$ See United Nations Security Council (2015).

9 For a good account on the origins of Somali piracy see Osei-Tutu (2011).

10 See Ploch et al. (2010); see also Contact Group on Piracy off the Coast of Somalia (2009). See Fig. 1 which shows a picture of European trawlers off the coast of Somalia.

11 See Marine Resources Assessment Group (MRAG) (2005).

12 Of the 439 word wide pirate attacks more than half of them were attributed to Somali piracy. See for example Alessi and Hanson (2014).
} 


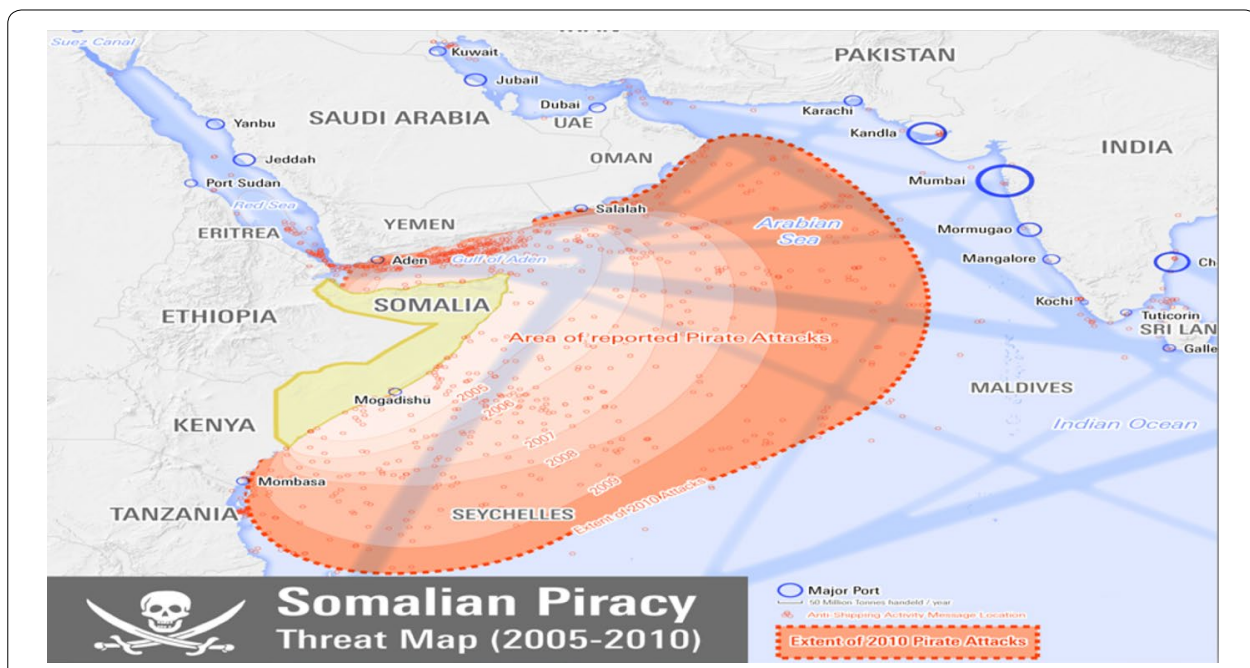

Fig. 1 Map of Somalia and adjoining territories

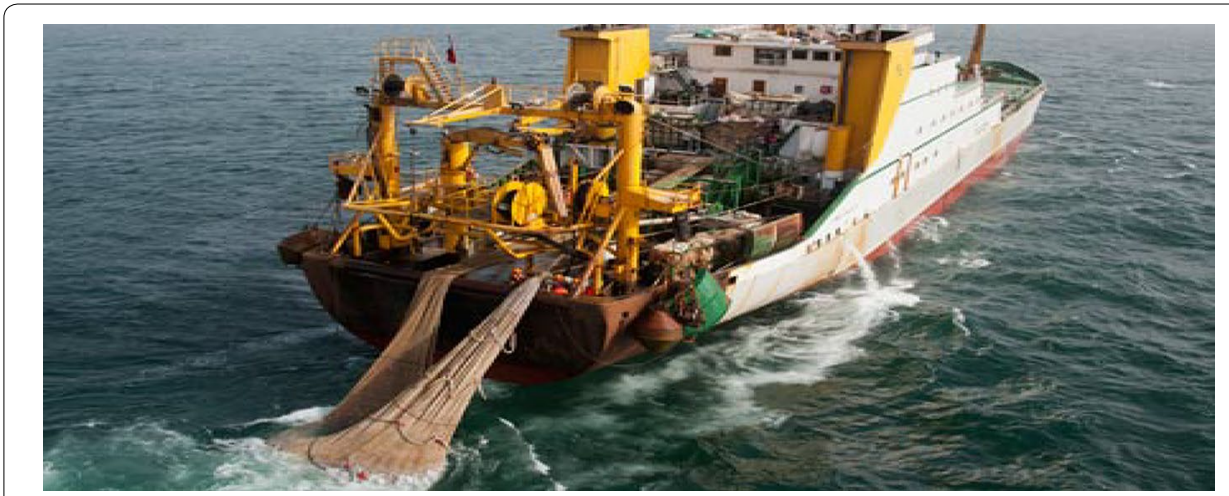

Fig. 2 European Trawler in Gulf of Aden

As will be seen below, for China (and the rest of the world) it is the same economic security that has forced them to cooperate against the Somali pirates.

The pirates operate in a gang of four to six people and are organized along networks (Gilpin 2007, p. 7). Their method of operation appears to be haphazardly executed while on shore their tactic of hijacking vessels and holding them, along with crew and cargo, to ransom is relatively sophisticated (Murphy 2009, p. 38). The lawless conditions in Somalia and one may add with the cooperation of fragile government authorities especially in Puntland, where it is possible to move a ship beyond the reach of rescue or retaliation, make it an ideal place for ransom based piracy to thrive. The ransom income of Somali pirates has probably been substantial. For example, the most successful group in the Southern Mudug region called the Xarardheere based 'Somali Marines', apparently demanded \$1 m and eventually settled for $\# 8000,000$ for the return of the Dongwon-ho, a South Korean tuna fishing vessel that was captured in April 2006. ${ }^{13}$

${ }^{13}$ It is estimated that in 2011 alone Somali piracy impact on global economy cost $\$ 7$ billion (Ploch et al. 2010). 
With the increasing success of such attacks and hijacking of sea vessels and the huge financial returns in the form of ransoms, the fortunes of these ex-fishermen changed and this resulted not only in a kind of organization or network for these earliest pirates but their success attracted many more Somalians, including, teachers, businessmen, militants working for several warlords, accountants and many more Somalians in other fields of human endeavor including Somali Diaspora (The Daily Monitor, 23rd November 2008, p. 20).

\section{China's role and implications for China's maritime security}

China, although a distant country, yet was affected severely by the piracy. A pointer in this case is the capture in November 2008 of two Chinese commercial ships by Somalian pirates and many Chinese taken as hostage. Not only that the fear of many more being captured and disrupting Chinese commercial traffic and sea lanes of communication loomed large prompting China to take steps to counter it. Noteworthy among the several steps taken by China since then, is to enhance Somalia's capacity. For China, Somalia's capacity building hence, is closely inter-twined with that of the security at the sea-for both the Somalians and China. Whereas the West sees Somalia and the problem of piracy as one associated with its failed status and the consequent threat posed by terrorist groups such as Al Shabaab, China's approach is markedly different in that it has sought to engage with Somalia a la other African countries by building its capacity in order that piracy can no more thrive and thereby provide a stepping stone to strengthen its relationship with Somalia. A couple of issues comes out of this development (1) Chinese maritime economic interests cannot be compromised and (2) China is taking a more assertive role in international affairs without compromising its foreign policy principle of non-interference in internal affairs (Andrew and Strange 2013, p. 3).

Accordingly, China has played a constructive role with regard to the piracy issue by way of (1) cooperating with the multinational task force to combating piracy and (2) simultaneously taking steps to adopt a comprehensive approach to maritime security. China's participation ${ }^{14}$ was a response to the piracy threat as per the UN Security Council resolution 1851 of 2008, which authorizes states to cooperate to counter piracy. Besides, it was with the sovereign consent of the Somali Transitional Federal government that China had sent its naval task forces to the Gulf of Aden. The state run China Daily reported that the "Chinese government supports the international community's decision to cooperate on the piracy problem according to international law and UN Security Council resolutions". ${ }^{15}$ And since its first offshore operation in 2008, China has sent about 16 naval task forces of not less than three ships in each force and has escorted several thousand ships both domestic and foreign. According to State media, the Chinese task forces consisted of "most advanced frigates, destroyers and amphibious ships and have escorted 5463 Chinese and foreign commercial ships, thwarted more than 30 potential pirate attacks, rescued over 40 commercial ships, and escorted 11 vessels previously taken by pirates". ${ }^{16}$

\footnotetext{
${ }^{14}$ See Chinese Naval Fleet Carries out First Escort Mission Off Somalia (2015)

15 See Navy Ships May Head to Somalia (2015).

16 See Andrew and Strange (2013).
} 
This shows not only China's cooperative role with the international community but also reflects its "key goal to register the presence of Chinese navy"17 and thereby to "demonstrate its desire to get maximum domestic and international publicity from the missions." ${ }^{18}$ As rightly noted by Kamerling Susanne (2011, p. 121) the Indian Ocean offers more opportunities for maritime newcomers such as China than do other Oceans. With the exception of India, the other littoral states of Indian Ocean are small powers but with a large population and with about $40 \%$ of the world coastline (Amit et al. 2011, p. 1). Hence the region has become important not only for countries to protect their respective interests but also to show case their international role and status. Important to note here is that China has been conducting naval drills to show case its power. According to Teshu Singh, ${ }^{19}$ the several naval drills conducted by China close to the GOA are meant to "demonstrate the growing reach of the country's maritime reach and power".

That apart, one can also note China's comprehensive approach to solve the problem. This was emphasized by the Somali Ambassador to the African Union at Beijing requesting China to find permanent solution to the problem by way of building Somali capacity to tackle the problem in the long run. ${ }^{20}$ Along this line, the Chinese Ambassador Huang Jemin called for a comprehensive approach to address the problem by "boosting the security capacity in Somalia, assisting economic development there and strengthening the capacity of other nations on that part of the Indian Ocean coast." ${ }^{21}$ In fact, during the decade spanning the cold war years between 1963 and 1971, Somalia received \$ 130 million in credits but with its collapse in 1991 the aid ended. ${ }^{22}$ However, China's aid to Somalia has resumed now. In fact, to these many countries in Africa, China has always been a welcoming phenomenon notable examples being Somalia's immediate neighbours in the Horn of Africa such as Ethiopia, the Sudan, Eritrea and Djibouti.

Besides, one should note that China's economic interests outside its region have grown tremendously leading to transformation in security priorities. From being a coastal defence force, Chinese Navy has now expanded its role to that of far seas. It has invested heavily in the development of ports in order to ensure reliable access to Chinese commercial shipping that uses the Red Sea and the Mediterranean Sea. ${ }^{23}$ This is largely owing to its expansion of bilateral economic ties with countries in Africa and Europe. Of worthy to note is the fact that China is now Africa's largest trading partner. Apart from its energy dependence ${ }^{24}$ China relies on large scale infrastructural projects for its state owned enterprises in addition to seeking sustained markets for exports particularly from Africa. The author is a witness to the huge infrastructural projects China has taken in Ethiopia and also in Kenya. All of these can be possible only when the transportation route is safe and sound.

\footnotetext{
${ }^{17}$ See http://www.chinadaily.com.cn/china/2008-12/17/content_7311735.htm.

${ }^{18}$ See Andrew and Strange (2013).

19 See Teshu (1997).

20 See Zhang (2015).

${ }^{21}$ See Weihua (2016).

22 See Shinn (2011).

${ }^{23}$ See Scott (2014).

${ }^{24}$ It is estimated that by 2030 its dependence on oil import through seas will increase to about $80 \%$ and hence maritime transport needs to be protected. See Andrew and Strange (2013), p. 13.
} 
Hence China feels compelled to attach importance to maritime security as most of its economic needs are met through the Oceans. Also, there is constant expansion of infrastructural projects in the Indian Ocean region in which new ports, rail systems and sea-based pipelines traverse across the Ocean to connect parts of West Asia for economic and trade purposes. New proposals have also been put forward to this effect highlighting the emphasis that this region has attained of late. For example, the recent proposals to set up a \$ 40 billion fund to support the Maritime Silk Road initiative by China along with developing a new Asian Infrastructure Investment Bank and a New Development Bank in which billions more would be contributed by China adds testimony to this. ${ }^{25}$ Hence, for China, securing and protecting the sea lines of communication (SLOCs) becomes all the more vital. It is obvious therefore that there is an increased deployment of naval power both by the littoral and extraregional powers to "support their respective ${ }^{26}$ national strategic and economic interests". ${ }^{27}$

In fact, China's Defence White Paper pubished in 2013 stresses that it will "protect national maritime rights and interests and national security interests in outer space and cyber space" and armed forces providing reliable support for China's interests overseas. ${ }^{28}$ This is also indicative of the shift in China's naval objectives from one of coastal defence to offshore defence and ultimately to far seas. A further testimony to this is the speech by the former Chinese President Hu Jintao at the 18th National CCP Congress in which he stressed that "We should attach great importance to maritime, space and cyberspace security". ${ }^{29}$ Notably, he emphasized the need to protect China's maritime interests saying:

We should enhance our capacity for exploiting marine resources, develop the marine economy, protect the marine ecological environment, resolutely safeguard China's maritime rights and interests, and build China into a maritime power.

The above is telling of the significance attached to maritime security by China. Notable with regard to the emphasis on far sea operations and preparedness is that it is not specific to any particular region or space; rather it is defined by Chinese maritime interest which, as noted above, has been expanding of late. In fact, China has been increasing its access to ports and airfields and making huge investments in infrastructure development and also attempting to establish base facilities with friendly countries like Sri Lanka as part of it Maritime Silk Route initiative. Therefore it is clear that China is embarking on expanding its influence commensurate with its expanding role and interests.

\section{Implications}

China's expanding role and interests has brought with it certain implications as well. Its increasing assertiveness beyond East Asia became noticed when it decided to send its naval forces to participate in counter piracy operations. This shows the balancing role of

\footnotetext{
25 See Chang (2014).

${ }^{26}$ Italics mine.

27 See Sakhuja (2014).

${ }^{28}$ http://eng.mod.gov.cn/Database/WhitePapers/2013-04/16/content_4442752.htm. Accessed 5th May 2015.

${ }^{29}$ See full text of the 18th National CCP Congress (2012).
} 
China commensurate with its rising status in the international community. This new venture was one of cooperative as compared to that of East and South China Sea corridors, which was one of forcefulness. Whatever the differences might be, the implications that one can draw from this is the extending economic and military influence that China is able to portray now. It is along this line that the much talked about Maritime Silk Road (MSR) Corridor project was proposed and which aims to enhance trade and sea connectivity and assist in the development of local economies. The MSR project "envisions an economic cooperation area stretching from the Western Pacific to the Baltic Sea as a sort of maritime highway buttressed by Chinese-supported infrastructure and port facilities in states straddling maritime routes along which China's trade and natural resources flow" (Singh 2014, p. 133). In fact, the project crosses the northern Indian Ocean to Nairobi, Kenya and goes north around the Horn of Africa and moving through the Red Sea into the Mediterranean, with a stop in Athens before meeting the land-based Silk Road in Venice. The Silk Road concept aims to "connect more than 50 countries via the sea and build a network of port cities along the Silk Road". ${ }^{30}$ The port facility that China has developed in Pakistan in Gwadar connecting Beijing with Gulf Countries and Arabian Sea enables China to transport oil through this facility and into China via land. ${ }^{31}$

Therefore, a foot hold in the Horn by way of re-opening of its embassy at Mogadishu in order to deal with the Somali piracy testifies China's future ambitions and desire. In this regard it is noteworthy to mention a report by the South China Morning post that China is expected to set up a network of offshore military supplies depot in strategic ports such as in Djibouti to protect its national interests. In fact, Agence France-Presse quoting the Djibouti President Ismail Omar Guelleh reported that talks were ongoing to enlist Beijing's military base in the country. ${ }^{32}$ Quoting a naval expert at the Chinese Naval Research Institute, the South China Morning Post said that it is inevitable that more overseas supply ports will be set up in Africa and other strategic areas as Chinese national interests expand. ${ }^{33}$ Understandably military bases in that part of the world would only go to support China's offshore commerce but it would also raise concerns on the part of extra-regional players particularly the USA which has been holding Djibouti base as part of its war on terror. Concerns are also there on the part of regional players such as India as to the real intentions of China which are viewed sceptical.

\section{Conclusions}

To conclude it is clear that China's participation in the counter piracy operations is owing to the impact it had on its maritime economic security and consequently its desire to extend its influence well beyond its sphere of influence. The 5 year long operation consolidated the Chinese navy as an Ocean going navy and an avenue to improve its ability to operate beyond its sphere of influence. The participation further enabled China to solidify its logistical support, coordinate with other countries, acted as an avenue

\footnotetext{
${ }^{30}$ See Narayan (2015).

31 See for details, Saibal (2015).

32 See Agence France Presse (2015).

33 See http://www.scmp.com/news/china/diplomacy-defence/article/1794667/china-sets-sights-offshore-military-depotsanalysts.
} 
to improve its confidence and finally make a mark among regional and extra-regional powers that it is a responsible player in the world and cannot be ignored in any nontraditional security issue affecting the international community. It also contributed to more close ties with Somalia and a foot hold in that part of the world with possibilities of establishing a military base in the near future. As was pointed out talks are already under way to establish such bases in Djibouti along with US base and the initiative for a maritime security road also envisages precisely this. While its positive contributions in such forms are welcome, time has come for major players including US and India to come to terms with China owing to its rising status. In other words, the intense responses from China to Somali piracy should not only be seen from the point of view of individual countries interest alone but also the need for cooperative and a responsible role that the international community should take while responding to such common issues and addressing them in a common platform. Cooperation is inevitable on major issues of common concern such as the climate change negotiations, Doha Trade round of talks, restructuring of global economic institutions like IMF, balancing USA supremacy etc., and more importantly that which was rightly exhibited by China in the case of Somali piracy. Be that as it may, time has come to accept China's role commensurate with its big power status. What remains to be seen is China's continued constructive role that takes on world leadership in a benign and constructive manner.

\section{Acknowledgements}

Author acknowledges the University of Madras for Granting permission to attend the conference and providing me with a supporting letter for the same. Acknowledgements are also due to my fellow colleagues in Addis Ababa University, Ethiopia for sending me some of the materials online.

Competing interests

The author declared that he has no competing interests.

Received: 18 September 2015 Accepted: 8 March 2016

Published online: 04 October 2016

\section{References}

http://indiatoday.intoday.in/story/india-china-maritime-dialogue-panchsheel-diamond-jubilee-indian-navy-pla-navyyang-jeichi/1/343577.html. Accessed 5th May 2015

Alessi, C, Hanson S. 2014. Combating maritime piracy. http://www.cfr.org/piracy/combating-maritime-piracy/p18376. Accessed 28th Dec 2014.

Amit, P., et al. 2011. Maritime commerce and security: the Indian Ocean. Washington: Stimson Center.

Andrew, E.S., and A. Strange. 2013. No substitute for experience: chinese anti-piracy operations in the Gulf of Aden. New Port: China Maritime Studies Institute, US Naval War College.

Bueger, Christian. 2015. What is maritime security?. Marine Policy 53:159-164. http://bueger.info/wp-content/ uploads/2014/12/Bueger-2014-What-is-Maritime-Security-final.pdf. Accessed 6th May 2015.

Buzan, B. 2009. People, states and fear: an agenda for international security studies in the post cold war era. United Kingdom: ECPR Press.

Chang, FK. 2015. Chinese submarines and the Indian ASW in the Indian Ocean, Foreign Policy Research Institute. http:// www.fpri.org/geopoliticus/2014/11/chinese-submarines-and-indian-asw-indian-ocean. Accessed 5th May 2015

China sets sights on offshore military depots: analysts. http://www.scmp.com/news/china/diplomacy-defence/article/1794667/china-sets-sights-offshore-military-depots-analysts. Accessed 14th May 2015.

Chinese naval fleet carries out first escort mission off Somalia. http://en.people.cn/90001/90776/90883/6568232.html. Accessed 14th May 2015.

Contact group on piracy off the coast of Somalia, fact sheet, bureau of political and military affairs. Jan 14, 2009. http:// www.state.gov/t/pm/rls/othr/misc/121054.htm. Accessed 18th Jan 2015.

Elmi, A.A. 2010. Understanding the Somali conflagration: identity. London: Pluto Press.

Fukuyama, F. 2004. The imperative of State building. Journal of Democracy 15(2):1-31.

Full text of the 18th National CCP Congress. http://www.china.org.cn/china/18th_cpc_congress/2012-11/16/content_27137540_9.htm. Accessed 8th May 2015.

Gilpin, R. 2007. Counting the costs of Somali piracy. Washington: United States Institute of Peace Working Paper. 
Holsti, K.J. 1996. The State, war and State of war. Cambridge: Cambridge University Press.

ICC International Maritime Bureau. 2010. Piracy and armed robbery against ships. London: Annual Report.

Lewis, M. 2003. A modern history of the Somali: nation and state in the horn of Africa (Eastern African Studies). Oxford: University Press.

Murphy, M.N. 2009. Small boats, weak states and dirty money. New York: Columbia University Press.

Narayan, M.K. 2015. To China with a clear strategy, 12. Chennai: The Hindu.

Navy Ships May Head to Somalia. http://www.chinadaily.com.cn/china/2008-12/17/content_7311735.htm. Accessed 11 th May 2015.

Osei-Tutu, JA. 2011. The root causes of Somali Piracy. KAIPTC Occasional Paper no. 31, March 2011 http://www.kaiptc.org/ Publications/Occasional-Papers/Documents/Occasional-Paper-31-Joana.aspx. Accessed 13th May 2015.

Ploch, L., C.M. Blanchard, R. Ronald O'Rourke, C. Mason, and R.O. King. 2010. Piracy off the Horn of Africa. Washington: Congressional Research Service.

Presse, AF. 2015. Djibouti President: China negotiating horn of Africa military base. http://www.defensenews.com/ story/defense/international/mideast-africa/2015/05/10/djibouti-president-china-negotiating-horn-africa-militarybase/27082879/. Accessed 14th May 2015.

Rahman, C. 2009. Concepts of maritime security. Auckland: Centre for Strategic Studies, Victoria University of New Zealand. Report by Marine Resources Assessment Group (MRAG). 2005. Review of impacts of illegal, unreported and unregulated fishing on developing countries, 1-178. London: Department of International Development.

Rider, D. 2015. China helps fight piracy off Somalia. http://www.neptunemaritimesecurity.com/china-helps-fight-piracysomalia/. Accessed 18th Feb 2015.

Saibal, D. 2015. China gets 40 year management rights on Pak's Gwadar Port and access to Arabian Sea", http://timesofindia.indiatimes.com/world/china/China-gets-40-year-management-rights-on-Paks-Gwadar-port-and-access-toArabian-Sea/articleshow/46923252.cms. Accessed 14th May 2015.

Sakhuja, V. 2014. Increasing maritime competition: IORA, IONS, Milan and the Indian Ocean Networks. New Delhi: Institute of Peace and Conflict Studies.

Scott, E. 2014. China's silk road strategy: a foothold in the Suez, but looking to Israel. China Brief. 14(19): 10-14.

Shinn, D.H. 2011. China and the horn of Africa. Washington: Middle East Studies Association.

Somali piracy exposes weakness in UN law of the sea. http://www.voanews.com/content/a-13-2009-04-08voa67-68785907/411065.html. Accessed 8th May 2015.

Susanne, K., and F.P. van der Putten. 2011. An overseas presence without overseas bases: China's counter piracy operations in the Gulf of Aden. J Curr Chin Affairs. 40(4): 119-146.

Teshu, Singh, 1997. Increasing maritime competition: IORA, IONS, Milan and the Indian Ocean Networks. In The maritime great game: India, China, US and the Indian Ocean, ed. Aparupa Bhattacherjee, 5. New Delhi: Institute of Peace and Conflict Studies. http://www.ipcs.org/pdf_file/issue/SR150-IPCSSpecialFocus-MaritimeGreatGame.pdf. Accessed 5th May 2015.

The Daily Monitor. 23rd Nov 2008. p. 20.

UN Data "Somalia", https://data.un.org/CountryProfile.aspx?crName=Somalia. Accessed 8th Jan 2015.

United Nations Security Council, Report of the Secretary-General pursuant to Security Council resolution 1846 (2008), dated 16th March 2009, S/2009/146. http://www.un.org/en/ga/search/view_doc.asp?symbol=S/2009/684. Accessed 18th January 2015.

Weihua, Chen. 2016. China helps fight piracy off Somalia. China Daily. http://www.chinadaily.com.cn/world/2014-12/08/ content_19040957.htm. Accessed 28th January 2016.

Zhang, H. 2015. Somalia welcomes Chinese naval presence. http://www.chinadaily.com.cn/china/2008-12/17/content 7313012.htm. Accessed 11th May 2015.

Zorawar, Daulet Singh. 2014. Indian perceptions of China's maritime silk road idea. J Defence Stud 8(4): 133-148.

\section{Submit your manuscript to a SpringerOpen ${ }^{\circ}$ journal and benefit from:}

- Convenient online submission

- Rigorous peer review

- Immediate publication on acceptance

- Open access: articles freely available online

- High visibility within the field

- Retaining the copyright to your article

Submit your next manuscript at $\boldsymbol{s p r i n g e r o p e n . c o m ~}$ 